\title{
Tryptophan depletion in normal volunteers produces selective impairment in memory consolidation.
}

Citation for published version (APA):

Riedel, W. J., Klaassen, T., Deutz, N. E. P., van Someren, A., \& van Praag, H. M. (1999). Tryptophan depletion in normal volunteers produces selective impairment in memory consolidation. Psychopharmacology, 141(4), 362-369. https://doi.org/10.1007/s002130050845

Document status and date:

Published: 01/01/1999

DOI:

10.1007/s002130050845

Document Version:

Publisher's PDF, also known as Version of record

Document license:

Taverne

Please check the document version of this publication:

- A submitted manuscript is the version of the article upon submission and before peer-review. There can be important differences between the submitted version and the official published version of record.

People interested in the research are advised to contact the author for the final version of the publication, or visit the DOI to the publisher's website.

- The final author version and the galley proof are versions of the publication after peer review.

- The final published version features the final layout of the paper including the volume, issue and page numbers.

Link to publication

\footnotetext{
General rights rights.

- You may freely distribute the URL identifying the publication in the public portal. please follow below link for the End User Agreement:

www.umlib.nl/taverne-license

Take down policy

If you believe that this document breaches copyright please contact us at:

repository@maastrichtuniversity.nl

providing details and we will investigate your claim.
}

Copyright and moral rights for the publications made accessible in the public portal are retained by the authors and/or other copyright owners and it is a condition of accessing publications that users recognise and abide by the legal requirements associated with these

- Users may download and print one copy of any publication from the public portal for the purpose of private study or research.

- You may not further distribute the material or use it for any profit-making activity or commercial gain

If the publication is distributed under the terms of Article $25 \mathrm{fa}$ of the Dutch Copyright Act, indicated by the "Taverne" license above, 
Wim J. Riedel • Tineke Klaassen • Nicolaas E.P. Deutz

Astrid van Someren · Herman M. van Praag

\section{Tryptophan depletion in normal volunteers produces selective impairment in memory consolidation}

Received: 13 February 1998/Final version: 8 July 1998

\begin{abstract}
Serotonin (5-hydroxytryptamine; 5-HT) circuits may play a role in cognitive performance, particularly in learning and memory. Cognitive impairment is often seen in depressed patients, in whom 5-HT turnover in the brain is thought to be lowered. A possible human pharmacological model to study the involvement of the serotonergic system in cognitive impairment is to reduce central 5-HT synthesis through L-tryptophan depletion in healthy subjects. In this study, the cognitive effects of tryptophan depletion were assessed and whether genetically or developmentally determined vulnerability factors were predictive of the cognitive impairment induced by tryptophan depletion. Sixteen healthy volunteers with a positive family history of depression and 11 without were given $100 \mathrm{~g}$ of an amino acid mixture with or without tryptophan, according to a double-blind, cross-over design. Tryptophan depletion specifically impaired long-term memory performance in all subjects: delayed recall performance, recognition sensitivity, and recognition reaction times were significantly impaired after tryptophan depletion relative to placebo. Short-term memory and perceptual and psychomotor functions were unchanged. There were no differences between groups with a positive and a negative family history for depression. On the basis of these results, it is concluded that tryptophan depletion specifically impairs long-term memory formation, presumably as a result of an acute decrease in 5-HT turnover in the brain.
\end{abstract}

W.J. Riedel $(\bowtie) \cdot$ T. Klaassen · A. van Someren

H.M. van Praag

Department of Psychiatry and Neuropsychology,

Brain and Behaviour Institute, European Graduate School for Neurosciences, Maastricht University, P.O. Box 616, 6200 MD Maastricht, The Netherlands

N.E.P. Deutz

Department of Surgery, Maastricht University, P.O. Box 616, 6200 MD Maastricht, The Netherlands

e-mail: wim.riedel@np.unimaas.nl, Fax: +31-43-3881046
Key words Attention - Cognition disorders etiology · Competing amino acids

Memory disorders chemically induced .

Serotonin biosynthesis - Serotonergic system ·

Tryptophan metabolism $\cdot$ Verbal learning

\section{Introduction}

The serotonergic system is considered important for learning and memory, and 5-HT function is reported to diminish with aging and in Alzheimer's disease (AD) and depression (McEntee and Crook 1991). In animal studies, stimulation of 5-HT activity in the brain impairs learning, memory (Altman and Normile 1988) and visual discrimination (Sirvio et al. 1994), whereas inhibition of 5-HT activity enhances learning and memory (Altman and Normile 1988) without affecting frontal lobe functions (Sirvio et al. 1994). Interestingly, 5-HT reuptake inhibitors improve memory performance in animals and humans (McEntee and Crook 1991), whereas interference with 5-HT synthesis or storage has been shown to induce depression in vulnerable individuals (Meltzer 1989). Patients with depression have decreased levels of 5-hydroxyindoleacetic acid (5-HIAA) in cerebrospinal fluid, decreased plasma tryptophan (TRP) concentrations, a low TRP to neutral amino acid ratio, and abnormalities in serotonergic function, as indicated by neuroendocrine challenge tests (Maes and Meltzer 1995), and reduced 5-HT synthesis in the brain (Grahame Smith 1992). Other serotonergic disturbances in depressed patients include upregulation of 5- $\mathrm{HT}_{2}$ and down-regulation of $5-\mathrm{HT}_{1 \mathrm{~A}}$ receptors (van Praag 1996). This serotonergic deficit may occur at any of several levels: diminished availability of precursor (TRP), impaired activity of tryptophan hydroxylase, abnormalities in 5-HT release or uptake, 5-HT receptor abnormalities, or interactions with other neurotransmitters (Maes and 
Meltzer 1995). The involvement of diminished serotonergic activity in mood disorders is evidenced by the fact that most antidepressants augment serotonergic activity (Blier and de Montigny 1994), while TRP depletion has a depressogenic effect (Young et al. 1985).

Cognitive dysfunctions are common, rather than rare concomitants of depression (Siegfried 1989) and are not restricted to single functions such as memory, drive or energy deficits, but affect all major cognitive abilities. Patients with depression have an impaired performance in recall and recognition memory (Brand et al. 1992), visual span (Deijen et al. 1993), complex information processing tasks (Tarbuck and Paykel 1995), and poor immediate and delayed free recall of verbal material (Ilsley et al. 1995). Antidepressant therapy, provided that anticholinergic side effects do not occur, often improves cognitive functions, and alleviates depression (Riedel and van Praag 1995). This improvement in cognitive functions may result from improved serotonergic, noradrenergic, or dopaminergic neurotransmission or from relief of the depressive symptoms.

Although experimentally induced serotonergic deficit, evoked by TRP depletion, causes depressed mood and cognitive impairment (Young et al. 1985; Danjou et al. 1990), there is no evidence that cognitive dysfunction in depression is specifically associated with 5-HT dysfunction. Until now there are only a few studies describing the effect of TRP depletion on human cognitive function. In two studies, an increased number of errors in a proofreading task was found (Young et al. 1985; Danjou et al. 1990). In one study, a specific impairment of learning and memory induced by TRPdepletion is reported (Park et al. 1994), while in another an effect of TRP depletion on focussed attention is found (Coull et al. 1995). Park et al. (1994) found an effect of TRP depletion in the absence of an effect on mood. They concluded that TRP depletion had relatively selective effects on cognitive function, namely impairments in learning and retrieval processes, while leaving performance on tests sensitive to frontal lobe dysfunction substantially unaffected. Coull et al. (1995) found that TRP depletion selectively increased the speed of stimulus-incompatible responses and not of compatible responses in an attentional search task. They concluded that serotonergic depletion might disrupt the inhibitory control of behavior.

The purpose of this study was to extend the findings of Park et al. (1994), using a word learning task paradigm in which effects of treatments on short-term memory and on long-term memory can be distinguished by multiple assessments as a function of time after word list presentation. In this manner, treatment effects on storage, consolidation and retrieval processes can be distinguished. The results reported by Park et al. suggest an effect on long-term memory processes (consolidation and retrieval), rather than on short-term memory (storage). Another purpose of the study was to determine the time course of TRP depletion. We wanted to see whether it was possible to maintain low TRP levels for $24 \mathrm{~h}$ by sustaining the TRP depletion treatment by a low TRP diet. It was postulated that, if TRP can be kept low for this period of time, the impact of low brain 5-HT would be augmented rather than diminished. This paradigm also allowed us to distinguish retrieval from consolidation processes by probing the word list learned on the previous day, followed by a new assessment of a parallel version of the word learning task, at $24 \mathrm{~h}$ after the start of the treatment. Furthermore, as specifically noted by Park et al., mood effects of TRP depletion may be linked to a vulnerability for depression factor, as several studies have shown this (Benkelfat et al. 1994; Park et al. 1994), but such an association has not been reported for vulnerability for depression and cognitive effects of TRP depletion.

Therefore we investigated the relation between 5-HT function and cognition in healthy volunteers and in healthy first-degree relatives of patients diagnosed as suffering from major depression. We postulated that (1) TRP depletion in healthy subjects would impair learning and memory and would attenuate response interference and hence may improve performance on stimulus-incompatible responses; (2) TRP depletion would impair signal-detection performance in a visual search task; and (3) healthy subjects with a positive family history of depression would be more vulnerable to the cognitive effects of TRP depletion than healthy subjects without a family history of depression.

\section{Materials and methods}

\section{Subjects}

Thirty-four healthy volunteers were recruited, of whom 15 women and 12 men completed the experiment [mean age $31 \pm 11$ (SD); range 18-61]. A complete medical examination was carried out. Exclusion criteria were cardiac, hepatic, renal, pulmonary, neurological, gastrointestinal, hematological, or psychiatric conditions, as determined from the history, physical examination, ECG, and routine laboratory blood screens, a history of alcohol or drug abuse, excessive drinking, and sensory or motor impairments which could reasonably be expected to affect psychomotor performance. A structured psychiatric interview, the MINI (Sheehan et al. 1994), was carried out to exclude psychiatric disorders. Dieting and susceptibility to the premenstrual syndrome were exclusion criteria. All subjects were furthermore screened for depression or manic-depressive illness in the past with Research Diagnostic Criteria (RDC) (Spitzer et al. 1975). All first-degree family members were contacted and had to meet Family History Research Diagnostic Criteria (Endicott et al. 1975) for depression in order to consider the subjects as having a family history of depression.

Two groups were formed, one with first-degree relatives with depression (positive family history: $\mathrm{FH}+$; seven males/nine females; $29 \pm 11$ years) and one group without first-degree relatives with depression ( $\mathrm{FH}-$; five males / six females; $33 \pm 11$ years). The study was approved by the standing Medical Ethics Review Committee of the University and written informed consent was given by all subjects. The subjects were paid for their participation. 
Study design

The study was conducted according to a full-factorial mixed design. The within-subjects Treatment factor had two levels: placebo $(\mathrm{T}+)$ and TRP depletion $(\mathrm{T}-)$. This factor was studied according to a two-period placebo-controlled, double-blind, cross-over design. Treatment order was balanced. The between-subjects factor was Family History for depression and consisted of two levels: positive $(\mathrm{FH}+)$ and negative $(\mathrm{FH}-)$.

\section{Treatment}

The TRP-free $(\mathrm{T}-$ ) mixture contained 15 free amino acids (AAs) and the placebo mixture contained the same AAs plus L-TRP (Young et al. 1985); see Table 1. Subjects were given a drink of $100 \mathrm{~g}$ AA mixture plus $300 \mathrm{ml}$ tap water, $33 \mathrm{~g}$ fat, and $63 \mathrm{~g}$ carbohydrates, flavoured with artificial orange or apricot in order to improve taste. Its total caloric value was $1000 \mathrm{kcal}$. Additional portions of $10 \mathrm{~g}$ of the drink were given at 7,11, and $13 \mathrm{~h}$ after ingestion of $100 \mathrm{~g}$. Furthermore, subjects were given a low TRP meal at lunch and dinnertime. This consisted of six slices of low protein bread $(0.2 \mathrm{~g} / \mathrm{slice})$ with margarine and marmalade, two pieces of fruit, tea, three glasses of lemonade, $200 \mathrm{~g}$ apple compote and mints (max. 50g).

\section{Assessments}

The cognitive test battery took approximately $40 \mathrm{~min}$ to complete and consisted of tasks measuring visual verbal learning, memory scanning, visual search and motor choice reaction time (MCRT). All tasks have been described in detail previously (Riedel et al. 1995) and will be described briefly below. However, the first two have been modified and will be described in detail below. The primary outcome variables were measures of memory functions; immediate and delayed recall and delayed recognition sensitivity and RT. The secondary outcome variables were measures of perceptual, attentional, psychomotor, and executive functions; slope and intercept of memory scanning, visual perceptual sensitivity and RT and simple RT, choice RT and stimulus-incompatible RT.

\section{The Visual Verbal Learning Test (VVLT)}

This test is an adapted version of the Rey Auditory Verbal Learning Test (Lezak 1995). The test consisted of a list of 30 monosyllabic words (18 nouns and 12 adjectives) in Dutch, which were presented in three trials on a computer screen. The words occur very frequently in Dutch and are acquired early in life. Items were presented in the same sequence at a rate of one per $2 \mathrm{~s}$. Each trial ended with a free recall of the words (immediate recall). Thirty minutes after the third trial, the subject was requested to recall as many words as possible (delayed recall). A yes/no recognition test, consisting of 15 former words and 15 new but comparable words, was given after the delayed recall test. The words remained on the screen for $2000 \mathrm{~ms}$ or until the subject responded. Another $1000 \mathrm{~ms}$ elapsed before the next word appeared on the screen. After presentation of each word, the subject had to respond "YES / NO" as fast as pos- sible to indicate recognition of the word (delayed recognition). The reaction times (RTs) were recorded. There were two different recognition lists to probe the long-term retention of each 30-word list. Both recognition lists consisted of 15 formerly learned and 15 new words (distractors). According to the theory of signal detection (Pollack and Norman 1964), the proportion of correctly recognized words (cr) and the proportion of falsely recognized (fr) constitute the non-parametric sensitivity measure: $\mathrm{A}^{\prime}=1-1 / 4$ (fr/cr + $(1-\mathrm{cr}) /(1-\mathrm{fr})) . \mathrm{A}^{\prime}$ is in fact the proportion of correctly recognized words, corrected for the subject's response tendency. Because the distribution of $\mathrm{A}^{\prime}$ is skewed due to a ceiling effect, $\mathrm{A}^{\prime}$ was $\arcsin$ transformed before being used in statistical analysis. In this study, word lists were presented at $t_{6}$ and at $t_{24}$. After $t_{6}$, delayed recall and recognition were assessed twice: once after a delay of $30 \mathrm{~min}$ $\left(\mathrm{t}_{6->6}\right)$ and once after a delay of $18 \mathrm{~h}\left(\mathrm{t}_{6->24}\right)$. After the list presented at $t_{24}$, recall and recognition were assessed only once after a delay of $30 \mathrm{~min}\left(\mathrm{t}_{24->24}\right)$. The variables used were the total number of words recalled after the first three trials as a measure of shortterm memory, the number of correct words on delayed free recall as a measure of retrieval from long-term memory (LTM), $\mathrm{A}^{\prime}$ as a measure of storage in LTM, and the median RT of correctly recognized target words as a measure of speed of retrieval from LTM. In each of the assessments, a different word list was presented. The lists were comparable with regard to their level of abstraction and the affective tone of the words. Parallel lists were order balanced over assessments.

\section{Memory scanning}

The subjects were briefly shown a set of one, two or four letters and told to memorize them. This is called the "memory set" (Sternberg 1969). Subjects then saw a series of 75 letters, each of them displayed for $1000 \mathrm{~ms}$ on a VCR connected to an IBM computer, followed by another $1000 \mathrm{~ms}$ before the next letter appeared. Half of the presented letters were part of the memory set and had to be recognized as targets. The subjects' task was to decide and respond as rapidly as possible by pressing either "YES" or "NO" to indicate whether or not each successive letter was one of those contained in the memory set. The median RT of correct responses (targets and non-targets) was taken as a dependent variable. Memory sets and stimulus sets were generated at random by the computer before each subtask. Individual RT * set size functions were calculated. This function is defined by the equation $\mathrm{RT}=\mathrm{A} *$ Ss $+B$, in which: $A=$ slope of the function (i.e. the amount of extra time needed per item in the memory set), Ss = size of the memory set, and $\mathrm{B}=$ intercept with the $\mathrm{Y}$-axis. The slope is a measure of the speed of scanning short-term memory, whereas the intercept measures sensorimotor speed.

\section{Visual Search Task}

Dots were presented on a computer screen in a random fashion. Every second, two dots changed position. When four dots formed a square, the subject had to push a button as quickly as possible (within $2 \mathrm{~s}$ ). Efficient and rapid visual search is required to obtain a high signal-detection performance on this task. The reaction time and the perceptual sensitivity measure $\mathrm{A}^{\prime}$ were taken as dependent variables.

Table 1 Composition of the placebo $(\mathrm{T}+) 100 \mathrm{~g}$ amino acid mixture. In the $\mathrm{T}-$ mixture the $3.0 \mathrm{~g}$ L-tryptophan is omitted

\begin{tabular}{|c|c|c|c|c|c|c|c|}
\hline $5.5 \mathrm{~g}$ & L-Alanine & $3.2 \mathrm{~g}$ & Glycine & $3.2 \mathrm{~g}$ & L-Histidine & $8.0 \mathrm{~g}$ & L-Isoleucine \\
\hline $13.5 \mathrm{~g}$ & L-Leucine & $8.9 \mathrm{~g}$ & L-Lysine & $5.7 \mathrm{~g}$ & L-Phenylalanine & $12.2 \mathrm{~g}$ & L-Proline \\
\hline $6.9 \mathrm{~g}$ & L-Serine & $6.5 \mathrm{~g}$ & L-Threonine & $6.9 \mathrm{~g}$ & L-Tyrosine & $8.9 \mathrm{~g}$ & L-Valine \\
\hline $4.9 \mathrm{~g}$ & L-Arginine & $2.7 \mathrm{~g}$ & L-Cysteine & $3.0 \mathrm{~g}$ & L-Methionine & $3.0 \mathrm{~g}$ & L-Tryptophan \\
\hline
\end{tabular}




\section{Motor Choice Reaction Time Task}

The subject held one button and was asked to press one of five other buttons located equidistantly from the hold button when lit. This yielded reaction times consisting of an initiation phase (time from stimulus onset until release of the hold button) and a movement phase (time from release of the hold button until the response button is pushed). The response set consisted of pressing the one button that lit up (simple RT), pressing one of three buttons which lit up (three-choice RT), or pressing the button to the right of the lit button (incompatible three-choice RT) as quickly as possible. Initiation times and movement times thus comprised the dependent variables obtained for each of the three reaction time tasks. This task measures sensorimotor speed, choice-reaction speed, and choice-reaction speed with response competition.

\section{Procedure}

A few days before the first experimental session, all subjects had individual training sessions in which they practiced all the tasks used in the study. Then the subjects received the first drink with or without TRP and completed the test battery. At least 4 days later, they received the other drink and completed the test battery. The subjects were not allowed any CNS-active drugs during the week before, or alcohol from $24 \mathrm{~h}$ before the testing sessions began. Day of the menstrual cycle was recorded; the distribution did not differ between treatment conditions. On the experimental day, at $9 \mathrm{~h}$ (baseline or $\mathrm{t}_{0}$ ) the drink was ingested as fast as possible, but within $2 \mathrm{~h}$. At $\mathrm{t}_{6}$ and at $\mathrm{t}_{24}$, all memory and cognitive tests were carried out; cognitive tests were also carried out at $t_{0}$. Blood samples for measurement of plasma TRP concentrations were taken at $t_{0}, t_{6}$ and $t_{24}$. Blood was immediately placed on ice and centrifuged within $30 \mathrm{~min}$ at $4^{\circ} \mathrm{C}$. A $100-\mu 1$ aliquot of plasma was mixed with $4 \mathrm{mg}$ sulfasalicyl acid and subsequently frozen at $-80^{\circ} \mathrm{C}$ until determination of AAs by high-performance liquid chromatography (van Eijk et al. 1993).

\section{Statistical analysis}

Primary and secondary outcome cognitive performance variables were analysed by using two-way repeated measures MANOVA (SPSS 6.1.1 on Apple Macintosh). Within subjects, factors were treatment condition $(\mathrm{T}-$ or $\mathrm{T}+)$ and in the memory scanning test and MCRT also the level of difficulty of the test: i.e. memory set $(1,2,4)$ and response set (simple, choice, incompatible). The between subjects factor was group $(\mathrm{FH}+/ \mathrm{FH}-)$. Changes in plasma concentrations of TRP and of other large neutral amino acids (LNAA's) and the ratio TRP/ $\Sigma$ LNAA's were analysed by using paired $t$-tests. Order effects were evaluated separately using treatment order $(\mathrm{T}+/ \mathrm{T}-$ or $\mathrm{T}-/ \mathrm{T}+)$ as a between-subjects factor.

\section{Results}

\section{Adverse effects}

During the study, seven subjects withdrew from the experiment after the first treatment session. Five subjects withdrew because of adverse effects related to the treatment: four subjects felt nauseous, three of whom vomited, and one subject could not adhere to the TRPpoor diet. One subject became ill the day after the treatment session, and one subject withdrew for no particular reason. All were women, six $\mathrm{FH}-$ and one $\mathrm{FH}+$, three in the $\mathrm{T}-$ and four in the $\mathrm{T}+$ condition.

\section{Missing data}

Twenty-seven subjects, 15 females and 12 males, completed the experiment. Because of difficulties in taking blood, blood samples were not available for two subjects in the $\mathrm{T}-$ condition at $\mathrm{t}_{6}$ and one subject at $\mathrm{t}_{24}$ and for two subjects in the $\mathrm{T}+$ condition at $\mathrm{t}_{24}$. Word learning data were missing for two subjects in the $t_{6->24}$ delayed recall trial, one in the $\mathrm{T}-$ and one in the $\mathrm{T}+$ condition and from two subjects in the $\mathrm{t}_{24->24}$ delayed recall trial, both in the T+ condition. Because of a computer failure, one subject at $t_{0}$ in the $\mathrm{T}+$ condition missed the Memory Scanning task and one subject at $t_{24}$ in the $T-$ condition missed the entire test battery including Recognition, Memory Scanning, Visual Search, and Choice RT. MANOVA analyses of variance were carried out without subjects with missing data at the relevant time points.

\section{Word learning}

The total number of words remembered in the immediate recall trials at $t_{6}$ did not differ between $\mathrm{FH}+/ \mathrm{FH}-$ groups and treatment conditions. Delayed recall performance of the word list presented at $\mathrm{t}_{6}$ was impaired in the $\mathrm{T}-$ condition at $\mathrm{t}_{6}\left(F_{1,25}=5.00\right.$, $P<0.05)$ and also at $\mathrm{t}_{24}\left(F_{1,23}=7.99, P<0.01\right)$. There were no differences between $\mathrm{FH}+/ \mathrm{FH}-$ groups. Immediate and delayed recall of the word list presented at $t_{24}$ did not differ between groups and treatment conditions. In Fig. 1, TRP depletion-placebo difference

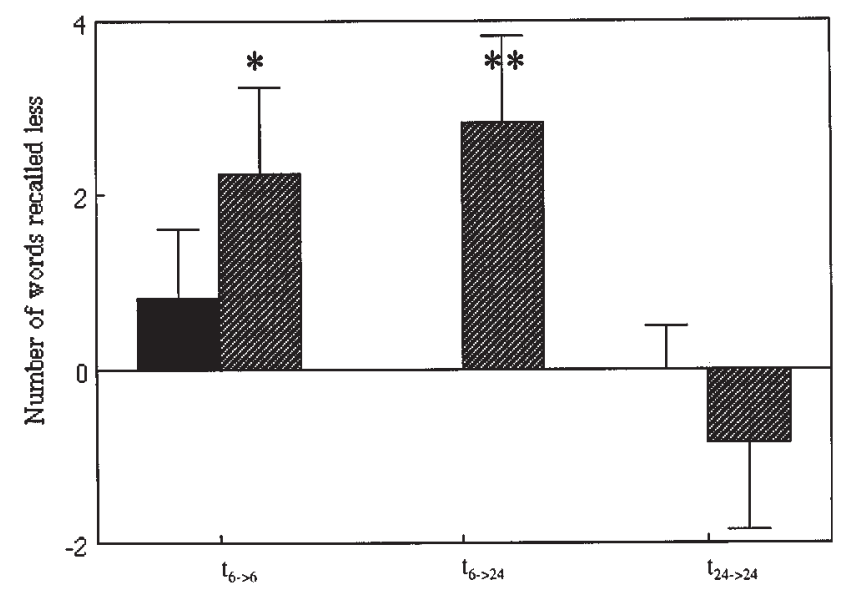

Fig. 1 Tryptophan depletion - placebo difference scores of immediate (black bars) and delayed recall (shaded bars) of word lists: presented and recalled at $\mathrm{t}_{6}\left(\mathrm{t}_{6->6}\right)$, presented at $\mathrm{t}_{6}$ and recalled at $\mathrm{t}_{24}\left(\mathrm{t}_{6->24}\right)$ and presented and recalled at $\mathrm{t}_{24}\left(\mathrm{t}_{24}>24\right)$. Positive scores denote impaired recall performance after TRP depletion relative to placebo. $* P<0.05 ; * * P<0.01$ 
scores are plotted as a function of time after presentation.

Recognition of the word list presented at $t_{6}$ did not differ between groups and treatment conditions at $t_{6}$, but at $\mathrm{t}_{24}$ recognition of the same word list was impaired in the T - condition $\left(F_{1,25}=4.43, P<0.05\right)$. There was no difference between the $\mathrm{FH}+/ \mathrm{FH}-$ groups. Recognition of the word list presented at $t_{24}$ did not differ between groups and treatment conditions. Speed (RT) of recognition of the word list presented at $t_{6}$ did not differ between groups and treatment conditions. At $\mathrm{t}_{24}$, speed of recognition of the same word list was slower in the $\mathrm{T}-$ condition $\left(F_{1,25}=10.77, P<0.005\right)$.
There was no difference between $\mathrm{FH}+/ \mathrm{FH}$ - groups, but there was an interaction effect of groups and treatment condition $\left(F_{1,25}=5.48, P<0.05\right)$. At $t_{24}$, both groups were slower at recognizing the words learned at $\mathrm{t}_{6}$ than they were at $\mathrm{t}_{6}$, and this slowing was more pronounced in the $\mathrm{FH}-$ group (+71 ms) than in the $\mathrm{FH}+$ group (+12 ms). Speed of recognition of the word list presented at $t_{24}$ did not differ between groups and treatment conditions. The results are listed in Table 2.

None of the secondary cognitive measures obtained for the memory scanning, visual search, and choice reaction time tasks differed between groups or treatment conditions. The results are listed in Table 3.
Table 2 The means and SE of the primary outcome measures obtained in word list learning: immediate recall, delayed recall and delayed recognition sensitivity and $\mathrm{RT}$, broken down by "Family history $(\mathrm{FH}+, \mathrm{FH}-)$ ", "Time of presentation $->$ recall $\left(\mathrm{t}_{6->6}\right.$, $\mathrm{t}_{6 \rightarrow>24}$ and $\left.\mathrm{t}_{24->24}\right)$ " and "Treatment $(\mathrm{T}+, \mathrm{T}-)$ ". $\mathrm{T}-$ results printed in italic are significantly different from placebo $(\mathrm{T}+)$

\begin{tabular}{|c|c|c|c|c|c|c|c|}
\hline \multirow[b]{2}{*}{ Measure } & \multirow[b]{2}{*}{ Treatment } & \multicolumn{3}{|c|}{$\mathrm{FH}+(n=16)$} & \multicolumn{3}{|c|}{$\mathrm{FH}-(n=11)$} \\
\hline & & $\begin{array}{l}\mathrm{t}_{6->6} \\
\text { Mean (SE) }\end{array}$ & $\begin{array}{l}\mathrm{t}_{6->24} \\
\operatorname{Mean}(\mathrm{SE})\end{array}$ & $\begin{array}{l}\mathrm{t}_{24->24} \\
\operatorname{Mean}(\mathrm{SE})\end{array}$ & $\begin{array}{l}\mathrm{t}_{6->6} \\
\text { Mean }(\mathrm{SE})\end{array}$ & $\begin{array}{l}\mathrm{t}_{6->24} \\
\operatorname{Mean}(\mathrm{SE})\end{array}$ & $\begin{array}{l}\mathrm{t}_{24->24} \\
\operatorname{Mean}(\mathrm{SE})\end{array}$ \\
\hline Immediate recall & $\mathrm{T}+$ & $41.7(3.2)$ & & $42.5(3.1)$ & $37.3(2.8)$ & & $39.5(2.7)$ \\
\hline (No. words correct) & $\mathrm{T}-$ & $38.4(3.6)$ & & $41.1(4.1)$ & $36.1(3.6)$ & & $41.5(3.1)$ \\
\hline Delayed recall & $\mathrm{T}+$ & $14.9(1.9)$ & $11.9(1.7)$ & $15.1(1.7)$ & $12.1(1.2)$ & $10.3(1.2)$ & $10.3(1.8)$ \\
\hline (No. words correct) & $\mathrm{T}-$ & $12.4(1.6)$ & $9.0(1.8)$ & $14.4(2.1)$ & $10.1(1.6)$ & $7.5(1.6)$ & $13.4(1.6)$ \\
\hline Delayed recog sens & $\mathrm{T}+$ & $92.1(2.6)$ & $87.9(2.6)$ & $90.1(3.6)$ & $88.1(2.5)$ & $82.4(2.9)$ & $88.9(2.7)$ \\
\hline (percentage) & $\mathrm{T}-$ & $90.9(1.4)$ & $79.3(5.5)$ & $89.5(2.4)$ & $88.9(2.5)$ & $80.0(3.7)$ & $91.4(2.1)$ \\
\hline Recognition RT & $\mathrm{T}+$ & $611(29)$ & $606(36)$ & $583(29)$ & $609(32)$ & $585(32)$ & $608(21)$ \\
\hline$(\mathrm{ms})$ & $\mathrm{T}-$ & $632(31)$ & $618(34)$ & $613(26)$ & $618(23)$ & $656(31)$ & $586(21)$ \\
\hline
\end{tabular}

Table 3 The means and SE of the secondary outcome measures: slope and intercept of the short-term memory scanning function, perceptual sensitivity and RT, simple RT, choice RT, S-R incom- patible RT and movement RT, broken down by "Family history (FH+, FH-)", "Time after treatment administration ( $\mathrm{t}_{0}$ or baseline, $\mathrm{t}_{6}$ and $\left.\mathrm{t}_{24}\right)$ " and "Treatment $(\mathrm{T}+, \mathrm{T}-)$ "

\begin{tabular}{|c|c|c|c|c|c|c|c|}
\hline \multirow[b]{2}{*}{ Measure } & \multirow[b]{2}{*}{ Treatment } & \multicolumn{3}{|c|}{$\mathrm{FH}+(n=16)$} & \multicolumn{3}{|c|}{$\mathrm{FH}-(n=11)$} \\
\hline & & $\begin{array}{l}\mathrm{t}_{0} \\
\text { Mean (SE) }\end{array}$ & $\begin{array}{l}\mathrm{t}_{6} \\
\text { Mean (SE) }\end{array}$ & $\begin{array}{l}\mathrm{t}_{24} \\
\text { Mean (SE) }\end{array}$ & $\begin{array}{l}\mathrm{t}_{0} \\
\text { Mean (SE) }\end{array}$ & $\begin{array}{l}\mathrm{t}_{6} \\
\text { Mean (SE) }\end{array}$ & $\begin{array}{l}\mathrm{t}_{24} \\
\text { Mean }(\mathrm{SE})\end{array}$ \\
\hline \multicolumn{8}{|c|}{ Short term memory scanning } \\
\hline Slope & $\mathrm{T}+$ & $37(4)$ & $34(4)$ & $32(5)$ & $27(3)$ & $30(4)$ & $27(4)$ \\
\hline (ms) & $\mathrm{T}-$ & $31(5)$ & $34(3)$ & $34(3)$ & $33(4)$ & $35(4)$ & $33(5)$ \\
\hline 1-Intercept & $\mathrm{T}+$ & $410(11)$ & $411(14)$ & $406(16)$ & $442(12)$ & $432(17)$ & $418(12)$ \\
\hline$(\mathrm{ms})$ & $\mathrm{T}-$ & $429(16)$ & 419 (13) & $411(13)$ & $430(13)$ & 415 (10) & $416(10)$ \\
\hline \multicolumn{8}{|l|}{ Visual search } \\
\hline Perceptual sens & $\mathrm{T}+$ & $84.3(1.9)$ & $81.9(2.8)$ & $82.7(2.7)$ & $81.3(2.7)$ & $84.2(2.8)$ & $84.4(2.4)$ \\
\hline (percentage) & $\mathrm{T}-$ & $81.8(1.8)$ & $83.5(2.8)$ & $82.6(2.6)$ & $82.4(3.3)$ & $82.2(2.8)$ & $81.3(3.1)$ \\
\hline Perceptual RT & $\mathrm{T}+$ & $763(13)$ & $757(20)$ & $756(26)$ & $772(26)$ & $764(21)$ & $744(26)$ \\
\hline$(\mathrm{ms})$ & $\mathrm{T}-$ & $773(24)$ & $767(20)$ & $747(20)$ & $759(24)$ & $742(19)$ & $744(24)$ \\
\hline \multicolumn{8}{|c|}{ Motor choice reaction time } \\
\hline$(\mathrm{ms})^{+}$ & $\mathrm{T}-$ & $279(7)$ & $276(7)$ & $285(10)$ & $306(8)$ & $283(9)$ & $287(6)$ \\
\hline 3-Choice RT & $\mathrm{T}+$ & $334(9)$ & $336(8)$ & $334(9)$ & $342(9)$ & $346(12)$ & $335(7)$ \\
\hline$(\mathrm{ms})$ & $\mathrm{T}-$ & $335(10)$ & $336(10)$ & $344(11)$ & $349(8)$ & $337(9)$ & $342(10)$ \\
\hline $\mathrm{S}-\mathrm{R}$ incomp RT & $\mathrm{T}+$ & 404 (11) & $390(13)$ & $396(15)$ & $414(14)$ & 413 (17) & 405 (19) \\
\hline$(\mathrm{ms})$ & $\mathrm{T}-$ & 409 (13) & $402(11)$ & $393(12)$ & $416(13)$ & $400(15)$ & $395(12)$ \\
\hline Movement time & $\mathrm{T}+$ & $120(5)$ & $115(5)$ & $119(6)$ & $131(11)$ & $126(10)$ & $128(8)$ \\
\hline (ms) & $\mathrm{T}-$ & $122(5)$ & $119(5)$ & $121(6)$ & $130(9)$ & $126(10)$ & $130(11)$ \\
\hline
\end{tabular}


Table 4 The means and SE of the blood plasma levels of TRP and the ratio TRP/ $L$ LNAAs. T - results printed in italic are significantly different from placebo $(\mathrm{T}+)$

\begin{tabular}{|c|c|c|c|c|c|c|c|}
\hline \multirow{2}{*}{$\begin{array}{l}\text { Time after } \\
\text { AA drink }\end{array}$} & \multirow[b]{2}{*}{ Treatment } & \multicolumn{3}{|c|}{$\mathrm{FH}+(n=16)$} & \multicolumn{3}{|c|}{$\mathrm{FH}-(n=11)$} \\
\hline & & $\begin{array}{l}\mathrm{t}_{0} \\
\text { Mean (SE) }\end{array}$ & $\begin{array}{l}\mathrm{t}_{6} \\
\text { Mean (SE) }\end{array}$ & $\begin{array}{l}\mathrm{t}_{24} \\
\text { Mean (SE) }\end{array}$ & $\begin{array}{l}\mathrm{t}_{0} \\
\text { Mean (SE) }\end{array}$ & $\begin{array}{l}\mathrm{t}_{6} \\
\text { Mean (SE) }\end{array}$ & $\begin{array}{l}\mathrm{t}_{24} \\
\text { Mean (SE) }\end{array}$ \\
\hline $\begin{array}{l}\text { TRP } \\
(\mathrm{mmol} / \mathrm{l})\end{array}$ & $\begin{array}{l}\mathrm{T}+ \\
\mathrm{T}-\end{array}$ & $\begin{array}{l}45.0(1.7) \\
45.6(1.9)\end{array}$ & $\begin{array}{l}54.8(5.3) \\
16.1(5.4)\end{array}$ & $\begin{array}{l}44.6(1.8) \\
40.3(3.4)\end{array}$ & $\begin{array}{l}49.7(2.9) \\
48.2(3.3)\end{array}$ & $\begin{array}{l}59.7(3.9) \\
15.0(3.1)\end{array}$ & $\begin{array}{l}46.9(3.6) \\
43.3(1.9)\end{array}$ \\
\hline $\begin{array}{l}\text { TRP/ } / \text { LNAA } \\
(\%)\end{array}$ & $\begin{array}{l}\mathrm{T}+ \\
\mathrm{T}-\end{array}$ & $\begin{array}{l}9.1(0.3) \\
8.8(0.4)\end{array}$ & $\begin{array}{l}7.3(0.6) \\
1.9(0.5)\end{array}$ & $\begin{array}{l}8.8(0.3) \\
7.4(0.3)\end{array}$ & $\begin{array}{l}9.1(0.5) \\
8.8(0.3)\end{array}$ & $\begin{array}{l}7.9(1.0) \\
2.2(0.7)\end{array}$ & $\begin{array}{l}8.3(0.5) \\
7.9(0.3)\end{array}$ \\
\hline
\end{tabular}

\section{Blood levels}

Plasma TRP concentrations at baseline and at $\mathrm{t}_{24}$ did not differ between groups and treatment conditions. Plasma concentrations of TRP were $67 \%$ lower at $\mathrm{t}_{6}$ than at baseline in the $\mathrm{T}-$ condition $\left(F_{1,22}=85.03\right.$, $P<0.0001)$. The ratio TRP $/ \Sigma$ LNAAs at baseline did not differ between groups and treatment conditions. This ratio was $78 \%$ lower at $t_{6}$ than at baseline in the $\mathrm{T}$-condition $\left(F_{1,22}=87.10, \quad P<0.0001\right)$ and was $15 \%$ lower at $\mathrm{t}_{24}$ than at baseline in the $\mathrm{T}$ - condition $\left(F_{1,21}=7.79, P<0.05\right)$. The results are listed in Table 4.

\section{Treatment order}

Thirteen subjects received the $\mathrm{T}-$ mixture first and 14 received the T+ mixture first. Analysis of the dependent variables by treatment order showed that there was no effect of treatment order on the effect of Ton delayed recall and delayed recognition. However, there was a complex interaction of treatment order with treatment and group on delayed recognition RT at $t_{6>24}$. The effect of T - on Recognition RT could largely be attributed to six subjects in the FH - group in whom $\mathrm{T}$ - slowed their RT by $125 \mathrm{~ms}$ and who received Tin the first session.

\section{Sex differences}

Although females tended to score better on immediate and delayed recall performance of the word learning task, the differences were not significant. The same was true for the effect of $\mathrm{T}-$ on delayed recall performance.

\section{Discussion}

To the best of our knowledge, this is the first study demonstrating the effects of TRP depletion specifically on long-term memory in humans. TRP depletion seemed to have a specific effect on LTM, with LTM consolidation being impaired $6 \mathrm{~h}$ after ingestion of a
TRP-free drink. Thus, information learned at $t_{6}$ seemed to be more rapidly forgotten between $t_{6}$ and $t_{24}$ by subjects in the TRP depletion condition than by subjects in the placebo condition. The finding that none of the other cognitive parameters were affected can be interpreted as an absence of TRP depletion effects on shortterm- or working memory, perceptual, attentional, psychomotor and executive functions. This highly specific effect of TRP depletion on LTM appears to confirm the findings of Park et al. (1994), who also reported specific long-term effects of TRP depletion on learning and memory. Regarding the specificity of the observed LTM impairment after TRP depletion, this seems to be a robust effect, as it is expressed by several parameters of LTM performance, which yield rather converging evidence that indeed LTM consolidation is impaired when information is presented at $\mathrm{t}_{6}$ after $\mathrm{T}-$. That is, information learned at $\mathrm{t}_{6}$ seems to more rapidly decay in the $30 \mathrm{~min}$ between immediate and delayed recall at $t_{6}$ and this difference is sustained in the $18 \mathrm{~h}$ between delayed recall at $\mathrm{t}_{6}$ and delayed recall at $t_{24}$ in the TRP-depletion condition relative to the placebo condition. Retrieval of newly learned material at $t_{24}$ is unaffected in the TRP-depletion condition relative to placebo, which leads us to conclude that consolidation rather than retrieval is affected. Further inspection of the difference in rate of decay of the learned words in the 18-h period between delayed recall at $t_{6}$ and delayed recall at $t_{24}$ between both treatment conditions reveals that the $\mathrm{t}_{6->24}$ decay in the $\mathrm{T}-$ condition is 3.4 words and 2.5 in the $\mathrm{T}+$ condition. This difference is not statistically significant $(t=-1.11$, $d f=24$; NS). As long-term memory is mainly formed during the minutes following presentation (Izquierdo 1989), the most plausible explanation of the $\mathrm{T}-$ effect on LTM performance is that T- hampers memory consolidation primarily during the $30 \mathrm{~min}$ between immediate recall and delayed recall. The difference in LTM performance would then be sustained in the 18-h period between delayed recall at $t_{6}$ and $t_{24}$. The finding that recognition performance is only impaired at $t_{24}$ might then be explained not by enhanced rate of decay in the period between $t_{6}$ and $t_{24}$, but merely by a threshold phenomenon which would be dependent on the time since presentation rather than on the rate 
of decay. Passive recognition is in general not a very sensitive procedure to test word learning, but might become so when the time between presentation and recognition is prolonged.

We assumed that TRP depletion would cause an acute reduction in 5-HT synthesis in the brain (Nishizawa et al. 1997). However, TRP depletion could also reduce protein synthesis (Cortamira et al. 1991), and drug-induced inhibition of protein synthesis in the brain is a model of memory disorders in experimental animals (Sarter et al. 1992). Moreover, if inhibition of protein synthesis is responsible for the LTM impairment observed after TRP depletion, then a similar effect should be observed after depletion of any other essential amino acid. This hypothesis was tested in a pilot experiment involving 13 subjects in which the effect of TRP depletion was compared to that of lysine depletion and placebo (Klaassen et al. 1999). The results showed that in contrast to TRP depletion, lysine depletion did not cause LTM impairments or have an effect on cognitive performance. Further experiments should be performed to confirm the effect of TRP depletion on LTM impairment and whether such depletion leads to a decreased synthesis of 5-HT. The lack of effect of TRP depletion on memory at $t_{24}$ was parallelled by the return of plasma TRP concentrations to normal. The TRP/ $\Sigma$ LNAA ratio was still significantly different between $\mathrm{T}-$ and $\mathrm{T}+$ at $\mathrm{t}_{24}$, but this difference was small and can probably be attributed to increased concentrations of LNAAs rather than low concentrations of TRP at $t_{24}$. The delayed recall and recognition impairments at $t_{24}$ of words learned at $t_{6}$ can be attributed to impaired consolidation of information between $t_{6}$ and $t_{24}$. At $t_{24}$, there were no longer impairments of memory for new information and neither were there any other cognitive effects of $\mathrm{T}-$. This was surprising, because we had intended that prolongation of the TRP deficient diet would lead to prolonged depletion of TRP and hence to prolongation or exaggeration of its effects on memory or cognitive performance. Even if TRP concentrations had returned to normal, there is no reason to assume that 5-HT concentrations would also return to normal. It would be reasonable to assume that there is a delay between the decline of TRP in plasma and 5-HT in the brain. There are two possible explanations for this lack of effect at $t_{24}$. The first is that the TRPdeficient diet did not in fact affect 5-HT concentrations, and the second is that the synthesis of 5-HT was restored, possibly by "recycling" of TRP released by protein degradation. A feature of the TRP depletion method in which our study differs from others is the addition of carbohydrates and fat to the AA mixture. One might raise the possibility that the addition of carbohydrates to the AA mixture alters the brain entry of TRP in an undesired manner. Carbohydrates are known to increase the rate of insulin release, thus taking away several LNAAs from the circulation, which might stimulate the uptake of TRP in the brain
(Fernstrom 1981). However, this logic only applies to protein-free meals. Protein-containing meals, or mixtures which strongly enhance protein synthesis such as our mixtures, would fail to rise brain TRP concentrations because their ingestion causes serum TRP concentrations and the concentrations of its transport competitors to rise by proportionally similar amounts, resulting in no net change in competition for uptake (Fernstrom and Fernstrom 1995). Meal-induced changes in brain TRP concentrations appear to be predicted by the alterations produced by the meal in the serum concentration of TRP relative to that of the other LNAAs, as expressed by the ratio TRP/ $\Sigma$ LNAAs (Fernstrom and Fernstrom 1995). As this ratio was convincingly low in our study, at least at $\mathrm{t}_{6}$, the addition of carbohydrates and fat to the AA mixture does not seem to alter the method of TRP depletion and hence did not corroborate the results. Furthermore, it must be noted that it is very difficult in general for the subjects to refrain from carbohydrates during a prolonged period of $24 \mathrm{~h}$. Adding carbohydrates to the AA mixture is a way to provide the subjects' necessary nutrition in a standard manner and besides might even contribute to a decrease of the brain entry of TRP, since it leads to a further enhancement of protein synthesis and would thereby bind (more) free TRP.

A family history of depression did not influence the results, and thus individuals with such a history would not appear to be more susceptible to the effects of TRP depletion on cognitive function. Further studies with larger numbers of subjects are needed to confirm this result. Another factor which could have affected the results is the sex of the subjects. Women are more susceptible to a lowering of mood as a function of TRP withdrawal (Ellenbogen et al. 1996). However, little is known about sex-related effects of TRP depletion on cognitive functions, because previous studies (Park et al. 1994; Coull et al. 1995) investigated only male subjects. Our data show that women had a somewhat greater memory impairment during TRP depletion, but this could also be an initial values problem, because the women had better memory performance at baseline.

The effect of $\mathrm{T}-$ on mood was also studied and the results showed that only $\mathrm{FH}+$ subjects showed a moodlowering response to $\mathrm{T}-$. These results were presented elsewhere (van Praag et al. 1997) and can be considered a replication of the findings by Benkelfat et al. (1994). There was no effect of FH on cognitive performance and since there appeared to be no association between cognitive and mood responses to $\mathrm{T}-$, it seems that these effects are not dependent on one another.

In conclusion, our data indicate that TRP depletion specifically impairs LTM consolidation in healthy human volunteers. The effect is presumed to be mediated via impaired synthesis of 5-HT and hence lowered 5-HT availability in the brain. The method used could 
serve as a model for studying cognitive dysfunction in 5-HT related disorders.

Acknowledgements This study was made possible by a grant from the Maastricht University's Hospital Clinical Research Fund ("Profileringsfonds").

\section{References}

Altman HJ, Normile HJ (1988) What is the nature of the role of the serotonergic nervous system in learning and memory: prospects for development of an effective treatment strategy for senile dementia. Neurobiol Aging 9:627-38

Benkelfat C, Ellenbogen MA, Dean P, Palmour RM, Young SN (1994) Mood-lowering effect of tryptophan depletion. Enhanced susceptibility in young men at genetic risk for major affective disorders. Arch Gen Psychiatry 51:687-697

Blier P, de Montigny C (1994) Current advances and trends in the treatment of depression [see comments]. Trends Pharmacol Sci $15: 220-226$

Brand AN, Jolles J, Gispen de Wied C (1992) Recall and recognition memory deficits in depression. J Affect Disord 25:77-86

Cortamira NO, Seve B, Lebreton Y, Ganier P (1991) Effect of dietary tryptophan on muscle, liver and whole-body protein synthesis in weaned piglets: relationship to plasma insulin. $\mathrm{Br}$ J Nutr 66:423-435

Coull JT, Sahakian BJ, Middleton HC, Young AH, Park SB, McShane RH, Cowen PJ, Robbins TW (1995) Differential effects of clonidine, haloperidol, diazepam and tryptophan depletion on focused attention and attentional search. Psychopharmacology 121:222-230

Danjou P, Hamon M, Lacomblez L, Warot D, et al. (1990) Psychomotor, subjective and neuroendocrine effects of acute tryptophan depletion in the healthy volunteer. Psychiatr Psychobiol 5:31-38

Deijen JB, Orlebeke JF, Rijsdijk FV (1993) Effect of depression on psychomotor skills, eye movements and recognition-memory. J Affect Disord 29:33-40

Ellenbogen MA, Young SN, Dean P, Palmour RN, Benkelfat C (1996) Mood response to acute tryptophan depletion in healthy volunteers: sex differences and temporal stability. Neuropsychopharmacology 15:465-474

Endicott J, Andreasen NC, Spitzer RL (1975) Family history research diagnostic criteria. Biometrics Research, New York State Psychiatric Institute, New York

Fernstrom JD (1981) Dietary precursors and brain neurotransmitter formation. Annu Rev Med 32:413-425

Fernstrom MH, Fernstrom JD (1995) Brain tryptophan concentrations and serotonin synthesis remain responsive to food consumption after the ingestion of sequential meals. Am J Clin Nutr 61:312-319

Grahame Smith DG (1992) Serotonin in affective disorders. Int Clin Psychopharmacol 4:5-13

Ilsley JE, Moffoot AP, O'Carroll RE (1995) An analysis of memory dysfunction in major depression. J Affect Disord 35:1-9

Izquierdo I (1989) Different forms of post-training processing. Behav Neural Biol 51:172-202

Klaassen T, Riedel WJ, Deutz NEP, van Someren A, van Praag HM (1999) Specificity of the tryptophan-depletion method. Psychopharmacology 141:279-286
Lezak MD (1995) Neuropsychological assessment, 3rd edn. Oxford University Press, New York

Maes M, Meltzer HY (1995) The serotonin hypothesis of major depression. In: Bloom FE, Kupfer DJ (eds) Psychopharmacology: the fourth generation of progress. Raven Press, New York, pp 933-944

McEntee WJ, Crook TH (1991) Serotonin, memory, and the aging brain. Psychopharmacology 103:143-149

Meltzer H (1989) Serotonergic dysfunction in depression. Br J Psychiatry Suppl 155 [Suppl 8]:25-31

Nishizawa S, Benkelfat C, Young SN, Leyton M, Mzengeza S, de Montigny C, Blier P, Diksic M (1997) Differences between males and females in rates of serotonin synthesis in human brain. Proc Natl Acad Sci USA 94:5308-5313

Park SB, Coull JT, McShane RH, Young AH, Sahakian BJ, Robbins TW, Cowen PJ (1994) Tryptophan depletion in normal volunteers produces selective impairments in learning and memory. Neuropharmacology 33:575-588

Pollack I, Norman DA (1964) A non-parametric analysis of recognition experiments. Psychon Sci 1:125-126

Riedel WJ, Van Praag HM (1995) Avoiding and managing anticholinergic effects of antidepressants. CNS Drugs 3:245-259

Riedel W, Hogervorst E, Leboux R, Verhey F, Van Praag H, Jolles J (1995) Caffeine attenuates scopolamine-induced memory impairment in humans. Psychopharmacology 122:158-168

Sarter M, Hagan J, Dudchenko P (1992) Behavioral screening for cognition enhancers: from indiscriminate to valid testing. Psychopharmacology 107:144-159

Sheehan D, Lecrubier Y, Janavs J, Knapp E, Weiller E (1994) MINI international neuropsychiatric interview. University of South Florida, Tampa

Siegfried K (1989) Depression and dementia of the Alzheimer type: implications for psychopharmacological research. Hum Psychopharmacol 4:237-245

Sirvio J, Riekkinen PJ, Jakala P, Riekkinen PJ (1994) Experimental studies on the role of serotonin in cognition. Prog Neurobiol $43: 363-379$

Spitzer RL, Endicott J, Robins E (1975) Research diagnostic criteria (RDC) for a selected group of functional disorders. 2nd edn. 2. Biometrics Research, New York State Psychiatric Institute, New York

Sternberg S (1969) Memory scanning: mental processes revealed by reaction time experiments. Am Sci 57:421-457

Tarbuck AF, Paykel ES (1995) Effects of major depression on the cognitive function of younger and older subjects. Psychol Med 25:285-295

van Eijk HM, Rooyakkers DR, Deutz NE (1993) Rapid routine determination of amino acids in plasma by high-performance liquid chromatography with a $2-3$ microns Spherisorb ODS II column. J Chromatogr 620:143-148

van Praag HM (1996) Serotonin related, anxiety/aggression driven, stressor precipitated depression: a psycho biological hypothesis. Eur Psychiatry 11:57-67

van Praag HM, Klaassen T, Riedel W, Honig A (1997) Prolonged tryptophan depletion and family history: effects on mood and memory. Biol Psychiatry 42:106S

Young SN, Smith SE, Pihl RO, Ervin FR (1985) Tryptophan depletion causes a rapid lowering of mood in normal males. Psychopharmacology 87:173-177 